\title{
Obowiązki wychowawcy klasy w szkołach średnich Drugiej Rzeczypospolitej
}

\begin{abstract}
The duties of form tutors in secondary schools in the Second Commonwealth of Poland
Educational influence is among the essential tasks of school activities. It should be performed by all the teachers and especially by form tutors. The modern model of the form tutor was formed during the interwar period. After Poland regained independence, it also gained the opportunity of creating its own schools and of conducting educational tasks in accordance with the needs of the country and the society. Educating the youth became one of the most important tasks. The duties of form tutors had to be redefined, too. The educational authorities issued the relevant regulations, which were popularised by educational magazines and introduced into schools under the guidance of school principals and teachers' boards.
\end{abstract}

Keywords: teaching, tutoring, secondary schools, history of education

\section{Wprowadzenie}

Jednym z zadań szkoły jest realizacja funkcji opiekuńczo-wychowawczej. Współczesny model nauczyciela-wychowawcy ukształtował się dopiero w dwudziestoleciu międzywojennym. Wcześniej, w okresie zaborów, nauczyciele szkół rządowych zmuszeni byli realizować politykę oświatową władz zaborczych, które dążyły do wynarodowienia Polaków. Wówczas obowiązek wychowania młodego pokolenia w duchu narodowym w całej pełni spoczywał na rodzinie. Na terenie byłego Królestwa Polskiego sytuacja uległa pewnej poprawie po wydaniu ukazu carskiego z 14 października 1905 r. - wówczas pojawiła się możliwość otwierania prywatnych szkół z polskim językiem wykładowym. Chociaż szkoły te nie posiadały praw, przysługujących gimnazjom rządowym, mogły jednak w większym niż dotąd stopniu decydować o kierunku kształcenia i wycho- 
wania młodzieży. W pozostałych placówkach sytuacja pod względem wychowawczym niewiele się zmieniła. Wychowawstwo na ziemiach byłego zaboru rosyjskiego po $1905 \mathrm{r}$. odegrało znaczącą rolę $w$ dziele utrzymania i pielęgnowania idei narodowej wśród młodzieży prywatnych polskich szkót średnich, a wychowawców dobierano starannie, jednak w pozostałych zaborach posiadało ono jedynie charakter formalny, sprowadzając się do wypełniania obowiązków gospodarza klasy, a sami zainteresowani traktowali swe czynności wychowawcy przygodnie, jako obowiazek ogólny wszystkich nauczycieli ${ }^{1}$.

Sytuacja zmieniła się po odzyskaniu niepodległości w 1918 r. Szkoła zaczęła funkcjonować w zupełnie odmiennej rzeczywistości. Realizacja polityki oświatowej własnego państwa pozwoliła na jawność życia szkolnego i wypełnianie zadań dydaktyczno-wychowawczych zgodnie z potrzebami państwa i społeczeństwa. Nauczyciele z ogromnym zapałem, chociaż często bez wystarczającego przygotowania, podejmowali pracę oświatową. Szczególną uwagę przywiązywano do wychowania obywatelskiego ${ }^{2}$. W pierwszych latach niepodległości utożsamiano je z wychowaniem narodowym, które wyraźnie zarysowało się już pod koniec XIX w., ale dopiero po 1918 r. zyskało oficjalny, sankcjonowany przez państwo charakter ${ }^{3}$. Wychowanie to miało na celu nie tylko przekazywanie tradycji narodowej, ale przede wszystkim przejmowanie z niej elementów wartościowych oraz tworzenie nowego modelu Polaka udoskonalonego, który potrafi zdobywać lepsza przyszłość dla całego narodu 4 . Po przewrocie majowym w 1926 r. idea państwa zdominowała ideę narodu i na plan pierwszy wysunęło się wychowanie państwowe. Zdaniem J. Balickiego wychowanie państwowe powinno dązyć do przyswojenia wychowankom wiadomości o państwie, jego czynnościach i organizacji, krzewiac $w$ ten sposób zrozumienie jego istoty i charakteru; do odpowiedniego nastawienia uczuciowego wzgledem idei państwowej, sprzyjajacego rozwojowi poczucia państwowego; do wyćwiczenia droga odpowiednich zabiegów woli, zdolnej w każdej chwili do czynnego spetniania obowiązków względem państwa ${ }^{5}$. Po 1935 r. nastąpił zwrot w kierunku wychowania obywatelsko-narodowego ${ }^{6}$.

W okresie międzywojennym powstało wiele opracowań, poruszających zagadnienie wychowawczej funkcji szkoły. O wychowaniu i roli wychowawców pisali: B. Nawroczyński,

1 R. Mańkowski, Regulamin pracy wychowawczej w szkołach średnich, „Przegląd Pedagogiczny” 1927, nr 34, s. 799-800.

2 J. Szafran, Dla dobra polskiej szkoty, Poznań 2010, s. 33.

3 F.W. Araszkiewicz, Ideały wychowawcze Drugiej Rzeczypospolitej, Warszawa 1978, s. 15.

${ }^{4}$ B. Nawroczyński, Zagadnienie wychowania narodowego, „Przegląd Pedagogiczny” 1929, nr 1, s. 8.

5 J. Balicki, Wychowanie państwowe $w$ dzisiejszej szkole średniej. Konferencja dyrektorów szkót średnich ogólnokształcacych okręgu szkolnego lwowskiego i warszawskiego w dniach od 10 do 15 marca 1930 r., „Przegląd Pedagogiczny” 1930, nr 13, s. 319.

${ }^{6}$ F.W. Araszkiewicz, Ideały wychowawcze..., s. 21; K. Jakubiak, Wychowanie państwowe jako ideologia wychowawcza sanacji, Bydgoszcz 1994, s. 44.

${ }^{7}$ B. Nawroczyński, Polska myśl pedagogiczna, Lwów 1933. 
K. Sośnicki ${ }^{8}$, F. Przyjemski ${ }^{9}$, H. Pohoska ${ }^{10}$, S. Łempicki ${ }^{11}$, M. Ziemnowicz ${ }^{12}$, W. Jasiń$\mathrm{ski}^{13} \mathrm{i}$ inni. W okresie powojennym i współcześnie pojawiły się $\mathrm{m}$. in. publikacje: F. W. Araszkiewicza ${ }^{14}$, S. Michalskiego ${ }^{15}$, K. Jakubiaka ${ }^{16}$, A. Smołalskiego ${ }^{17}$, J. Szafran ${ }^{18}$. Brakuje jednak opracowań opartych na analizie artykułów zamieszczanych w czasopismach pedagogicznych, które docierały przecież do szerokiego grona nauczycieli-wychowawców, kształtowały ich poglądy, system wartości i wpływały na określone zachowania. Czasopisma pełniły ważną rolę w kształtowaniu zarówno ideałów wychowawczych, jak i modelu nauczyciela-wychowawcy, dlatego też za podstawę źródłową niniejszego opracowania przyjęłam artykuły publikowane w kierowanym do nauczycieli szkół średnich „Przeglądzie Pedagogicznym” z lat 1918-1939 i dodatku do tego czasopisma pt. „Sprawy Towarzystwa Nauczycieli Szkół Średnich i Wyższych”19.

Po odzyskaniu niepodległości wychowanie dzieci i młodzieży stało się jednym z najważniejszych zadań szkoły. Należało więc określić obowiązki tych, którzy pełnili tę odpowiedzialną funkcję. Władze oświatowe podjęły zadanie opracowania przepisów, normujących obowiązki wychowawców, ich propagowaniem wśród nauczycieli zajęły się czasopisma pedagogiczne, natomiast nad realizacją czuwały dyrekcje szkół i rady pedagogiczne.

\section{Wychowawcza funkcja szkoły i nauczycieli}

Od 1920 r. w „Przeglądzie Pedagogicznym” pojawiały się artykuły dotyczące wychowawczej funkcji szkoły i obowiązków nauczycieli. W jednym z nich K. Kulwieć i H. Lipski zamieścili projekt instrukcji ministerialnej, dotyczącej realizacji zadań wychowawczych w szkole. Podkreślili w niej, że zadaniem szkoły jest nie tylko przekazywanie wiedzy, ale też wychowanie młodzieży na dzielnych i prawdziwie pożytecznych obywa-

${ }^{8}$ K. Sośnicki, Podstawy wychowania państwowego, Lwów 1933.

${ }^{9}$ F. Przyjemski, O polski system wychowawczy, Kraków 1930.

${ }^{10}$ H. Pohoska, Wychowanie obywatelsko-państwowe, Warszawa 1931. 1938.

11 S. Łempicki, Polskie tradycje wychowawcze, Warszawa 1936; idem, Polski ideat wychowawczy, Lwów

12 M. Ziemnowicz, Problemy wychowania współczesnego, Warszawa 1927.

13 W. Jasiński, Na przełomie myśli wychowawczej, Poznań 1936.

${ }^{14}$ F. W. Araszkiewicz, Ideały wychowawcze; idem, Tadeusza Jana Łopuszańskiego koncepcja szkoty średniej ogólnokształcacej, Rydzyna 1987; idem, Szkoła średnia ogólnokształcąca w Polsce w latach 1918-1932, Wrocław 1972.

15 S. Michalski, Działalność pedagogiczna Anieli Szycówny, Warszawa 1968; idem, Społeczna i pedagogiczna działalność Stefanii Sempołowskiej na tle epoki, Warszawa 1973.

${ }^{16}$ K. Jakubiak, Wychowanie państwowe jako ideologia wychowawcza sanacji, Bydgoszcz 1994.

${ }_{17}$ A. Smołalski, Ideały wychowawcze w polskiej myśli pedagogicznej od XXI w. do końca II Rzeczypospolitej, Opole 1994; idem, Wizje nauczyciela w polskiej myśli pedagogicznej do 1939 r., Opole 1997.

18 J. Szafran, Dla dobra polskiej szkoty, Poznań 2010.

19 Dalej: „Sprawy Towarzystwa”. 
teli odrodzonej Ojczyzny ${ }^{20}$. Dlatego wszyscy pracownicy pedagogiczni szkoły powinni czuć się odpowiedzialni za realizację tego zadania. Każda lekcja musi być świadomie godzina wychowywania, na której nauczyciel przykładem swej punktualności, sumienności, zapałem, jaki w swa codzienna pracę wkłada, umiejętnościa utrzymania klasy w należytym, a tak nieodzownym dla owocnej pracy nastroju, żywym przykładem, po stokroć lepszym od słownych nauk, daje młodzieży wskazówki, jak należy pojmować $i$ wypetniać przyjęte obowiazki, jak powinna odbywać się zbiorowa praca społeczna ${ }^{21}$. Powinien wymagać od uczniów stałego, równego i starannego przygotowania lekcji, sumiennego i dokładnego odrabiania zadań $i$ ćwiczeń, gdyż w ten sposób nauczy ich wytrwałości i systematyczności w dążeniu do celu ${ }^{22}$. Kilka lat później jeden z wychowawców pisał: Najskuteczniejszym się nam jednak wydaje stały i nieustanny dozór nad każdym krokiem chłopca, rano pobieżnie sprawdzić przygotowane lekcje, prosić nauczycieli o częstsza dokładna kontrolę, informować się o przebiegu każdej lekcji, przypilnować, aby lekcje zadane na jutrzejszy dzień byty zanotowane, nawet $w$ ostrzejszych przypadkach prosić rodziców o podpis każdodzienny pod zanotowanymi lekcjami itp. Niezbędny jest tu stały kontakt szkoły z domem. Powyższe ma na celu wytworzenie przyzwyczajeń, które by z biegiem czasu staty się druga natura ucznia ${ }^{23}$.

Kilka lat później w 1929 r. Naczelnik Wydziału Szkolnictwa Średniego w Ministerstwie Wyznań Religijnych i Oświecenia Publicznego, K. Pieracki, podkreślał, że Ministerstwo zwraca szczególną uwagę nie tylko na poziom dydaktyczny, lecz także wychowawczy szkół. Powinni o tym pamiętać zwłaszcza właściciele i kierownicy szkół prywatnych, dążących do zdobycia dla swych placówek pełnych praw, przysługujących gimnazjom państwowym ${ }^{24}$. Jednocześnie zastanawiano się, kto w szkole powinien wychowywać młodzież. Na placówki te społeczeństwo i władze oświatowe nakładają coraz więcej obowiązków wychowawczych, tymczasem nauczyciele są często przeciążeni obowiązkami dydaktycznymi, zaś dyrektor wiele czasu poświęca sprawom kancelaryjnoadministracyjnym, ponosi też odpowiedzialność za poziom dydaktyczny szkoły, więc na działalność wychowawczą lub choćby tylko kontrolę w tym zakresie brakuje już czasu ${ }^{25}$. Należy więc odciążyć dyrektorów od nadmiernych obowiązków i zrozumieć, że nie mogą oni sami ponosić za wszystko odpowiedzialności ${ }^{26}$.

${ }^{20}$ K. Kulwieć, H. Lipski, Projekt instrukcji dla wychowawców klasowych, „Przegląd Pedagogiczny” 1920, nr 2, s. 74.

${ }^{21}$ Ibidem.

22 Ibidem.

${ }^{23}$ Z teki wychowawcy, ,Sprawy Towarzystwa” 1925, nr 5-7, s. 73.

${ }_{24}$ J. Szczepański, O poziom naukowy $i$ wychowawczy $w$ szkołach prywatnych, „Przegląd Pedagogiczny” 1929, nr 6, s. 137.

25 T.B., Na tematy wychowawcze, „Przegląd Pedagogiczny” 1930, nr 24, s. 539-540.

26 J.W., Dola dyrektorów, „Przegląd Pedagogiczny” 1936, nr 5, s. 61. 


\section{Zadania wychowawcy klasy}

W szkole pracują osoby, szczególnie powołane do wychowywania młodzieży. Są to wychowawcy klasowi. Do wychowawcy klasowego uczeń musi mieć bezwzględne zaufanie. Wychowawca powinien sam, nawet nieproszony przez ucznia, służyć mu radą i pomocą, ale w sposób taktowny. Do tego potrzebna jest dobra znajomość wychowanków. Opiekun klasy powinien jak najwięcej przebywać z uczniami przed lekcjami, w czasie przerw, podczas zastępstw za nieobecnych nauczycieli oraz prowadzić z nimi rozmowy, aby zorientować się, którzy uczniowie jakiej pomocy potrzebują. W niektórych przypadkach będzie konieczne nawiązanie bliższych kontaktów z rodzicami uczniów, wizyta $\mathrm{w}$ ich domach rodzinnych lub na stancjach. Szczególną uwagę należy zwrócić na dzieci i młodzież, u których pojawiły się problemy dydaktyczno-wychowawcze. Znając warunki domowe, wychowawca będzie mógł skuteczniej pomóc. Powinien też stać się obrońcą interesów ucznia w kontaktach z innymi nauczycielami. Bez jego opinii nie należy decydować o losach dziecka w szkole. Wychowawca klasy dba też o właściwe zachowanie uczniów po dzwonku na lekcjach i w czasie rozchodzenia się do domów po zakończonych zajęciach. Powinien dążyć do tego, aby uczniowie sami, niejako automatycznie, regulowali swoje zachowanie odpowiednio do sytuacji, bez ciągłej interwencji dorosłych, aby stopniowo zanikała potrzeba ciągłego ich dozorowania. Wychowawca jest też ,wyrazicielem zarządzeń” władz szkolnych - od sposobu zapoznania z nimi młodzieży, wyjaśnienia ich potrzeby i celowości, zależy stopień przestrzegania tych zarządzeń przez uczniów. Jest więc również twórca opinii klasy $w$ sprawach doniostych [...], kieruje zbiorowym sumieniem małego, a tak wrażliwego i łatwo obcym wpływom ulegajacego społeczeństwa ${ }^{27}$. Musi pamiętać o rzeczach na pozór drobnych, a jednak $w$ skutkach doniostych - wdrażaniu uczniów do utrzymania czystości, ładu i porządku w klasie, poszanowaniu cudzej i wspólnej własności, utrzymaniu czystości ubioru, zeszytów i książek, o tym, ̇̇e na czas maja być przyniesione kreda, gabka, mapy czy obrazy, podane dziennik czy pióro $^{28}$. Wychowawca powinien wypowiedzieć walkę spóźnieniom i opuszczaniu lekcji. Do jego zadań należy kontrolowanie obecności uczniów na lekcjach, zapisywanie planu lekcji, odczytywanie uwag zapisanych w dzienniku przez innych nauczycieli, notowanie postępów uczniów z poszczególnych przedmiotów i zapisywanie ich w dziennikach; powinien też prowadzić korespondencję i rozmowy z rodzicami lub opiekunami uczniów. Do jego zadań należy również projektowanie ocen sprawowania, pilności $i$ uwagi, zbieranie różnych danych statystycznych o uczniach, pilnowanie, aby dni robocze były równomiernie obciążone, wreszcie inne jeszcze czynności, których ilość i jakość zależa w dużym stopniu od warunków każdej poszczególnej szkoty ${ }^{29}$. Ma też obowiązki wobec uczniów poza szkołą: organizowanie wycieczek klasowych i towarzyszenie klasie podczas wycieczek ogólnoszkolnych, które dostarczają młodzieży zdrowej rozrywki, zapoznają z pięknem kraju, jego zabytkami i różnymi gałęziami przemysłu,

\footnotetext{
27 K. Kulwieć, H. Lipski, Projekt instrukcji, s. 76.

28 Ibidem, s. 77.

${ }^{29}$ Ibidem.
} 
techniki i rzemiosła. Stwarzają też okazję do nawiązania odpowiednich stosunków wychowawcy z młodzieżą, są okazją do obserwacji uczniów, pozwalają lepiej poznać ich upodobania i charakter. Sumienne i umiejętne wypełnianie przez wychowawcę jego obowiązków pomoże szkole przysposobić ucznia do zaopatrzenia się w wiedzę $i$ wyrobienie $w$ nim zalet, potrzebnych do osiagnięcia osobistego powodzenia $w$ życiu oraz ukształtować młodego człowieka na jednostkę samodzielnie pożyteczna dla społeczeństwa ${ }^{30}$. Celem wychowawcy nie jest przekazanie młodzieży wiadomości, ale ukształtowanie w niej zdolności do samodzielnego zdobywania wiedzy i samodzielnego wyrabiania $w$ sobie przekonań etycznych i społecznych, że powinien on kierować samodzielnym rozwojem ucznia, wskazywać mu drogi, do celu najprędzej wiodace, oszczędzać pomyłek i błąkań, rozstrzygać watpliwości, skracać chwile wahań i niepewności, prostować poglady fatszy$w e^{31}$. Zadania wychowawcy są zbieżne z zadaniami szkoły, które polegają na rozwijaniu młodzieży w dwóch kierunkach - należy wzbogacać ja w wiedzę i takie zalety charakteru oraz nawyknienia, które moga jednostke przygotować do skutecznej walki o byt osobisty oraz wyrobić $w$ młodzieży cnoty obywatelskie, wyćwiczyć te strony charakteru i ugruntować takie nawyknienia i upodobania, jakie sa niezbędne, aby jednostka stała sie wartościowa społecznie, aby Ojczyzna pozyskała $w$ tej młodzieży prawych obywateli, dzielnych działaczy społecznych ${ }^{32}$. Na ucznia oddziałują także dom rodzinny i szersze otoczenie społeczne - należy uodpornić młodego człowieka na wpływy szkodliwe poprzez wyrabianie odpowiednich cech charakteru - samodzielności, godności i odpowiedzialności osobistej, a wówczas szkoła wypuści w świat jednostki o zdecydowanym zarysie duchowym, jednostki zdolne do pracy twórczej, charaktery, na których sile i prawości społeczeństwo będzie mogło polegac ${ }^{33}$. Wychowawca organizuje dla młodzieży konferencje wychowawcze, poświęcone podstawowym problemom życia zbiorowego, np. zagadnieniu władzy, konieczności ładu i porządku, objawom życia społecznego w klasie szkolnej, opinii publicznej, poczuciu obowiązku społecznego i narodowego, poczuciu honoru osobistego i zbiorowego itp. Działania te nie tylko przyczynią się do uporządkowania warunków pracy szkolnej, wpłyną też na ukształtowanie u wychowanków istotnych cech: pracowitości, rzetelności, gruntowności, planowości, konsekwencji, ładu i porządku. Te kardynalne cnoty, których taki brak odczuwamy w naszym społeczeństwie dojrzatym, nie dadza się rozwinać u młodzieży inaczej i prędzej, jak droga ćwiczenia się $w$ nich już w szkole ${ }^{34}$.

W sytuacjach trudnych wychowawca powinien mieć oparcie w istniejącej w szkole Radzie Wychowawców. Aby nauczyciel skutecznie oddziaływał na młodzież, musi pracować z niezbyt liczną grupą wychowanków, a praca wychowawcy w szkole nie może być traktowana jako zajęcie uboczne, że obowiąki jego nie moga być poczytywane za

\footnotetext{
${ }^{30}$ Ibidem.

31 Ibidem, s. 79.

32 Ibidem s. 75.

33 Ibidem, s. 79.

34 Ibidem, s. 83.
} 
dodatkowe do nauczania. Przeciwnie, stanowisko wychowawcy w szkole winno być w całej organizacji szkolnej wysunięte na czoło ${ }^{35}$.

F. Fuchs zastanawiał się jednak, czy szkoła ma wychowywać w petnym znaczeniu tego słowa, czy kształcić $i$ wychowywać w rozumieniu skromniejszym i ciaśniejszym tego po$j e ̨ c i a^{36}$. Był przeciwny zbyt szerokiemu rozumieniu zadań wychowawczych instytucji oświatowej, gdyż sądził, że żadna placówka nie może przywłaszczać sobie zbyt szerokich zadań kosztem rodziny, że szkoła nie może zawsze $i$ wszędzie wychowywać $i$ wychowywać sama w całości i niemal bez reszty ${ }^{37}$, a ograniczanie rodziców w ich obowiązkach wychowawczych traktował jako zamach na ich wolność obywatelską. Publicysta przekonywał, że szkoła może być $i$ powinna zakładem wychowawczym, ale tylko $w$ pewnym ograniczonym znaczeniu $i$ tylko do pewnego stopnia, a zawsze tak, aby wplyw innych, bardzo licznych $i$ bardzo ważnych czynników, a przede wszystkim rodziców $i$ domu rodzinnego, nie ulegt poważniejszemu uszczupleniu ${ }^{38}$.

W lutym 1922 r. odbył się Zjazd Dyrektorów Państwowych Szkół Średnich, poświęcony obradom nad zapisami instrukcji, opracowanej przez Ministerstwo Wyznań Religijnych i Oświecenia Publicznego ${ }^{39}$. Ministerstwo poprosiło ogół nauczycieli o wyrażenie opinii w tej sprawie. Aby ułatwić wszystkim zainteresowanym zapoznanie się z dokumentem, Zarząd Główny Towarzystwa Nauczycieli Szkół Średnich i Wyższych zapowiedział wydanie drukiem broszurki, zawierającej tekst instrukcji. Jednocześnie w numerze 7 „Przeglądu Pedagogicznego” z 1922 r. zamieszczono „Zarys obowiązków opiekuna klasowego w szkole średniej ogólnokształcącej”, obejmujący czynności wychowawcze, wychowawczo-administracyjne i administracyjno-kancelaryjne. Do czynności wychowawczych zaliczono: poznawanie uczniów i interesowanie się życiem klasy; organizowanie życia zbiorowego młodzieży; budzenie jej zainteresowań społecznych poprzez tworzenie organizacji samorządowych, rozwijanie zmysłu społecznego, karności i poczucia odpowiedzialności za działalność w grupie; budzenie i rozwijanie uczuć narodowych i patriotycznych, zmysłu państwowego; podnoszenie poziomu kultury obyczajowo-towarzyskiej, estetycznej i zamiłowań naukowych; czuwanie nad wychowaniem fizycznym; utrzymywanie kontaktów z domem rodzinnym wychowanków oraz oddziaływanie na środowisko rodzinne; poznawanie warunków życia i pracy uczniów poza szkołą, ich potrzeb oraz organizowanie w miarę możliwości stosownej pomocy. Zakres czynności wychowawczo-administracyjnych obejmował: nadzór nad przestrzeganiem przepisów szkolnych; kontrolę nieobecności i spóźnień; porozumiewanie się w sprawach uczniów z innymi nauczycielami, lekarzem szkolnym i dyrektorem szkoły; udział w lekcjach nauczycieli, uczących w danej klasie; udział w konferencjach wychowawczych; sporządzanie charakterystyk uczniów, uwzględniających ich rozwój umysłowy i moralny; sporzą-

\footnotetext{
35 Ibidem, s. 84-85. s. 141.

${ }^{36}$ F. Fuchs, Szkoła ogólnokształcąca jako zakład wychowawczy, „Przegląd Pedagogiczny” 1920, nr 4,

37 Ibidem, s. 147.

38 Ibidem, s. 154.

39 Dalej: Ministerstwo WRiOP.
} 
dzanie i przedstawianie na posiedzeniach Rady Pedagogicznej szczegółowych planów pracy opiekuńczej i wniosków wychowawczych; składanie dyrekcji szkoły pod koniec semestru sprawozdań z działalności wychowawczej. Do zadań administracyjno-kancelaryjnych wychowawcy zaliczono: czuwanie nad stanem dziennika klasowego i zestawianie co pewien czas danych na temat nieobecności i spóźnień uczniów; sporządzanie katalogów okresowych i głównych, przygotowywanie sprawozdań okresowych dotyczących przerobionego materiału nauczania, sporządzanie statystyk klasyfikacyjnych oraz pisanie świadectw szkolnych i korespondencja z rodzicami; przedstawianie sprawozdań o stanie klasy na konferencjach okresowych; przedstawianie wniosków natury administracyjnej, dotyczących całej klasy lub poszczególnych uczniów, na posiedzeniach Rady Pedagogicznej ${ }^{40}$. Wychowawca klasy powinien mieć co najmniej 1 godzinę tygodniową na pracę z samorządem klasowym. Jest to czas na wyrobienie w uczniach karności, poznanie ich zainteresowań, problemów, warunków domowych. Powinien też dążyć do wyeliminowania złych nawyków i wskazać młodzieży właściwe sposoby spędzania czasu wolnego. Znaczne korzyści może przynieść uczniowi udział w kółkach zainteresowań, jednak wychowawca musi dbać o właściwy dobór zajęć przez poszczególnych uczniów i czuwać, aby nie byli zbyt przeciążeni pracą pozalekcyjną ${ }^{41}$. Do jego zadań należy też wyrabianie w młodzieży koleżeństwa, solidarności, zmysłu społecznego, zrzeszania się, zdolności do współpracy, poczucia odpowiedzialności za siebie i innych, kultu czynu społecznego i pracy ideowej ${ }^{42}$. Pod koniec lat 30 . coraz więcej miejsca poświęcano współpracy szkoły z rodzicami uczniów, szczególną rolę przypisując wychowawcy klasy. Od jego umiejętności komunikacyjnych i taktu zależało powodzenie w nawiązaniu właściwych kontaktów z rodzicami i opiekunami uczniów ${ }^{43}$.

Zwrócono też uwagę na rozbieżności między funkcją społeczną i stanowiskiem społecznym nauczyciela-wychowawcy. Nauczyciel szkoły średniej pełni istotną rolę kształcąc i wychowując przyszłą elitę społeczną, z drugiej jednak strony nie jest doceniany w społeczeństwie. Często jest traktowany jak urzędnik wykonujący polecenia władz szkolnych, a przecież powinien uczestniczyć z zaangażowaniem w przemianach społecznych. Od tego, na ile twórczo podejdzie do swych obowiązków, zależy opinia społeczna o wartości i godności zawodu pedagoga ${ }^{44}$.

\footnotetext{
40 Obowiązki opiekuna klasowego, „Przegląd Pedagogiczny” 1922, nr 7, s. 3-6.

${ }^{41}$ E. Szteinbokówna, Z aktualnych zagadnień wychowawczych, „Przegląd Pedagogiczny” 1929, nr 20, s. $478-479$.

${ }^{42}$ Konferencja dyrektorów szkót średnich ogólnokształcących okręgu szkolnego lwowskiego $i$ warszawskiego w dniach od 10 do 15 marca 1930 r., „Przegląd Pedagogiczny” 1939, nr 13, s. 319.

${ }^{43}$ K. Kiersnowski, Zagadnienie wspótpracy domu ze szkoła. Nieporozumienie, „Przegląd Pedagogiczny” 1938, nr 21, s. 311-312; J. Jasnota-Bzowski, Zagadnienie współpracy domu ze szkoła. Scylla i Charybada, „Przegląd Pedagogiczny” 1938, nr 22, s. 324-326; J. Rendzerowa, Zagadnienie wspótpracy domu ze szkoła. Rodzice i szkoła, „Przegląd Pedagogiczny” 1938, nr 20, s. 287-290; J. Ptaszycki, Zagadnienie wspótpracy domu ze szkoła. O wlaściwe podejście szkoły do domu, „Przegląd Pedagogiczny” 1938, nr 23, s. 343-347; R. Chirowski, Trochę prawdy o wspótpracy domu ze szkoła, „Przegląd Pedagogiczny” 1938, nr 17-18, s. 239-243.

${ }^{44}$ B. Suchodolski, Powołanie wychowawcy, „Przegląd Pedagogiczny” 1935, nr 6, s. 90.
} 


\section{Wymagania stawiane wychowawcom}

Trudno przewidzieć wszystkie sytuacje i zadania, które w swej pracy napotyka wychowawca. Musi więc on być osobą, która potrafi poradzić sobie w nowych sytuacjach, dlatego ważny jest jego umyst żywy, jego serce, pełne miłości dla uczącej się młodzieży, jego sumienie, przejęte świadomościa poważnych obowiązków i odpowiedzialnościa, jakie na siebie przyjąt $t^{45}$. Przy powierzaniu nauczycielom obowiązków wychowawczych zwracano uwagę na umiejętność tatwego i chętnego obcowania z młodzieża, nie tylko na lekcjach [...], lecz właśnie poza lekcjami, a nawet poza szkoła, w roli starszego towarzysza, doświadczonego doradcy i szczerego przyjaciela ${ }^{46}$. Dlatego Zjazd Dyrektorów Gimnazjów Państwowych w 1922 r. postanowił pracę wychowawcza w szkołach powierzać tylko najbardziej odpowiednim jednostkom wśród personelu nauczycielskiego danego gimnazjum - na to stanowisko powinni być powoływani ludzie wybitnie zrównoważeni, odznaczający się stanowczościa, ale petni rozumnej wyrozumiałości, cieszacy się powaga i szacunkiem wśród uczniów, a obok tego przystępni, fizycznie całkowicie zdrowi ${ }^{47}$. Należy też powołać Radę Wychowawców, która będzie uzgadniać decyzje, trudne do podjęcia przez pojedyncze osoby. A. Ryniewicz na początku lat 30. XX w. podkreślał, że nawet największe zdolności naukowe, wybitny dar wymowy nie zrobi z nauczyciela dobrego wychowawcy, jeżeli równocześnie będzie on człowiekiem niskim pod względem wartości moralnych. Im wyższy natomiast będzie jego poziom etyczny tym potężniejsze i podnioślejsze będzie promieniowanie jego duszy na wychowanków ${ }^{48}$. Dobry wychowawca wykazuje skłonność do podejmowania oddziaływań wychowawczych, ma uzdolnienia w tym zakresie, kocha młodzież, która nosi w sobie zadatki przyszłych wartości etycznych i narodowych oraz posiada silna wole do trwałego wptywania na jednostki wychowywane, przy równoczesnym uwzględnieniu osobistych ich cech $i$ wartości ${ }^{49}$. Najbardziej pożądany na tym stanowisku jest typ człowieka społecznego, który cała wartość życia widzi w pracy dla społeczeństwa, dąży do dokonana czegoś pożytecznego dla innych ${ }^{50}$. Wychowawca powinien mieć spokojne, pogodne usposobienie, tzw. humor pedagogicz$n y^{51}$. Jest to wielki dar, dany tylko nielicznym pedagogom, jednak każdy nauczyciel powinien pamiętać, że uśmiech ułatwia nawiązanie kontaktów z dziećmi i młodzieżą.

Wychowawca, aby dobrze wypełniać swoje obowiązki, powinien dokształcać się. W latach 30. na łamach czasopism pedagogicznych niejednokrotnie informowano o kur-

45 K. Kulwieć, H. Lipski, Projekt instrukcji, s. 84-85.

46 Ibidem, s. 75.

${ }^{47}$ Kronika Towarzystwa. Sprawozdanie z I Zjazdu Dyrektorów Gimnazjów Państwowych w dn. 3 i 4 lutego 1922 r. w Warszawie, ,Sprawy Towarzystwa” 1922, Nr 9, s. 7-8.

48 A. Ryniewicz, O powołaniu nauczyciela-wychowawcy, „Przegląd Pedagogiczny” 1930, nr 10, s. 227.

49 Ibidem, s. 228-229.

50 Ibidem, s. 228.

51 Ibidem, s. 229. 
sach i konferencjach dla dyrektorów szkół i wychowawców ${ }^{52}$. Uczono na nich poznawania wychowanków i ich potrzeb, zapoznawano z nowymi metodami pracy. Dyrektorzy biorący udział w szkoleniach organizowanych przez Ministerstwo WRiOP lub organizacje nauczycielskie na zebraniach Rady Pedagogicznej przekazywali zdobyta wiedzę nauczycielom, organizując w ten sposób dokształcanie swych pracowników na terenie szkoły.

\section{Przeszkody w realizacji obowiązków wychowawczych}

W związku z projektem instrukcji w sprawie obowiązków opiekunów klasowych $\mathrm{Ku}$ ratorium Okręgu Lwowskiego w dniu 2 grudnia 1921 r. wystosowało do dyrekcji podległych szkół okólnik w tej sprawie. W jednym z punktów zobowiązało opiekunów klasowych do wpisywania w dzienniku klasowym wszystkich czynności i zabiegów wychowawczych, podejmowanych poza lekcjami szkolnymi, z dokładnym określeniem czasu ich trwania. Spotkało się to z protestem zarówno opiekunów klas, jak i lwowskiego Zarządu Okręgowego Towarzystwa Nauczycieli Szkół Średnich i Wyższych ${ }^{53}$. Członkowie Zarządu sądzili, że jest to przepis kontrolny, który ubliża czci nauczycielskiej, a wychowanie jest rzecza zbyt subtelna, ażeby się dało ująć w minutowe cyfry, czasem zreszta krótka rozmowa na ulicy lub $w$ ogrodzie publicznym może mieć głębsze wychowawcze znaczenie, niż np. wielogodzinne nadzory $w$ teatrze lub fotoplastikonie ${ }^{54}$.

Ze względu na dużą ilość obowiązków wychowawców postulowano, aby nie przydzielać im (jeśli to tylko możliwe) większej liczby godzin niż przewiduje ich etat, ponieważ muszą mieć czas dla powierzonych im uczniów. Jeśli nauczyciel opiekuje się jedną klasą, powinien otrzymać wynagrodzenie jak za 10 godzin nadliczbowych, jeśli sprawuje opiekę nad dwoma klasami - przysługuje za tę pracę wynagrodzenie w takiej wysokości, jak za 16 godzin nadliczbowych. Musi być też zwolniony z niektórych czynności kancelaryjnych, aby wszystkie godziny szkolne poświęcić pracy wychowawczej5. Należy dokładnie wyznaczyć zakresu pracy wychowawczej, aby zapobiec nadmiernemu przeciążeniu wychowawców i ich zagubieniu w nawale pracy ${ }^{56}$.

W ustawie o uposażeniu funkcjonariuszy państwowych i wojska z 9 października 1923 r. uznano wychowawstwo za jeden $z$ dodatkowych obowiązków nauczyciela i przyznano za te czynności niewielkie wynagrodzenie - jak za 4 godziny tygodniowo lekcji

\footnotetext{
${ }^{5}$ Kronika. Konferencje dyrektorów w sprawach wychowawczych, „Przegląd Pedagogiczny” 1929, nr 10, s. 242; ht., Kursy dla wychowawców zorganizowane przez Koło Warszawskie TNSW, „Przegląd Pedagogiczny” 1930, nr 8, s. 185-187; Konferencja dyrektorów, s. 318-319.

53 Dalej TNSW.

${ }^{54}$ Memoriał lwowskiego Zarządu Okręgowego TNSW w sprawie okólnika Kuratorium z dn. 2 grudnia 1921 r., „Sprawy Towarzystwa” 1922, nr 14, s. 20-21.

55 Kronika Towarzystwa. Sprawozdanie, s. 8.

56 T.B., Na tematy wychowawcze, s. 540.
} 
z I kategorii przedmiotów nauczania ${ }^{57}$. Za opiekę nad samorządem oraz organizacjami młodzieży nie przyznano zapłaty ${ }^{58}$. Jednak dodatek za wychowawstwo był zbyt niski, by zrównoważyć włożone trudy. Szkolnictwo prywatne przyznało więc wychowawcom wynagrodzenie nieco wyższe, chociaż na mocy uchwat Komisji Norm przyjęło za podstawe wynagradzania swoich pracowników płace nauczycieli szkół państwowych ${ }^{59}$.

We wrześniu 1924 r. Kuratorium Okręgu Szkolnego Krakowskiego wydało okólnik, w którym rozdzieliło funkcje wychowawcy (sprawowaną odpłatnie) od funkcji gospodarza klasy (nie przewidziano za tę pracę wynagrodzenia). Podobną decyzję zakomunikowało dyrekcji podległych sobie szkół Kuratorium Okręgu Szkolnego Lwowskiego. W obu okólnikach zaznaczono, że osoby, które chcą ubiegać się o stanowisko wychowawcy, a nie tylko gospodarza klasy, powinny złożyć oferty, zawierające opracowany przez nich program wychowawczy. Zarówno Zarząd Okręgowy Lwowski, jak i Koło Krakowskie TNSW, wystąpiły w obronie nauczycieli i postanowiły, że wychowawcy nie powinni składać takich ofert. Sprawowanie funkcji gospodarza klasy uznały za jednoznaczną z wychowawstwem. Zapowiedziały też, że TNSW postara się uzyskać wygrodzenie u Ministra WRiOP również za sprawowanie funkcji gospodarza klasy ${ }^{60}$. Zgodnie z tą obietnicą w dniu 14 października 1924 r. delegacja Zarządów Okręgów Krakowskiego i Lwowskiego udała się do Ministra WRiOP z memoriałem w sprawie zarządzeń Kuratoriów dotyczących rozdziału wychowawstwa i gospodarstwa klasowego oraz przedstawiania przez nauczycieli ofert dotyczących obowiązków wychowawczych. Minister B. Miklaszewski poparł stanowisko zarządów okręgowych i zapowiedział wdanie rozporządzenia o obowiązkach opiekunów klas ${ }^{61}$. W styczniu 1925 r. Minister WRiOP zapowiedział zwołanie wkrótce konferencji, której ustalenia stanowić będa podstawę do ostatecznego uregulowania sprawy opiekuństwa klasowego ${ }^{62}$.

W grudniu 1925 r., na skutek trudnej sytuacji państwa zatwierdzono ustawę o zapewnieniu równowagi budżetowej, czyli tzw. ustawę sanacyjną ${ }^{63}$. Zgodnie z jej postanowieniami zniesiono $\mathrm{m}$. in. wynagrodzenie za wychowawstwo ${ }^{64}$. TNSW podjęło starania o przywrócenie wynagrodzenia za te czynności, w tym również wynagrodzenia za obowiązki wychowawcy, opiekę nad bibliotekami, gabinetami przedmiotowymi, za duszpasterstwo i inne czynności dodatkowe, przewidziane w art. 35 i 52 ustawy z dnia 9 paź-

\footnotetext{
${ }^{57}$ Ustawa o uposażeniu pracowników państwowych i wojska z dn. 9 października 1923 r. (Dz. Urz. Min. WRiOP nr 20 (121) z 1 grudnia 1923 r.)

${ }^{58}$ H. Kopia, Ustawa o uposażeniu, „Sprawy Towarzystwa” 1923, nr 31-32, s. 485.

59 W sprawie wychowawstwa, „Przegląd Pedagogiczny” 1926, nr 25, s. 676.

${ }^{60}$ O wychowawstwo, „Sprawy Towarzystwa” 1924, Nr 22, s. 359.

${ }^{61}$ Sprawa wychowawstwa i gospodarstwa klasowego na obszarze byłej Galicji, „Sprawy Towarzystwa” 1924, nr 29, s. 467.

${ }^{62}$ Odpowiedź Ministra WRiOP w sprawie obowiązków wychowawcy klasy, „Sprawy Towarzystwa” 1925 , nr 5-7, s. 81 .

${ }^{63}$ Ustawa o zapewnieniu równowagi budżetowej z dn. 22 grudnia 1925 r. (Dz. U. R.P. z 1925 r., Nr 129, poz. 918).

${ }^{64}$ R. Mańkowski, Regulamin, s. 800; Wynagrodzenie za wychowawstwo, „Przegląd Pedagogiczny” 1938, nr 21, s. 302.
} 
dziernika 1923 r. o uposażeniu funkcjonariuszy państwowych i wojska ${ }^{65}$. Wszyscy spodziewali się, że postanowienia Ustawy Sanacyjnej zostaną dość szybko cofnięte. Tak się jednak nie stało. W Warszawie powstała więc specjalna Komisja Porozumiewawcza, złożona z osób należących do Stowarzyszenia Dyrektorów Polskich Szkół Średnich Państwowych oraz do TNSW. Chodziło o dostosowanie działalności wychowawczej w szkołach do nowych warunków. 23 czerwca 1926 r. opracowano i zatwierdzono „Zakres obowiązków wychowawczych w państwowych szkołach średnich ogólnokształcących”, który miał obowiązywać w Warszawie jedynie w r. szk. 1926/27 lub do czasu cofnięcia zapisów ustawy sanacyjnej. Dokument ten ograniczał zakres obowiązków wychowawców, sprowadzając zajęcia administracyjne i formalne do niezbędnego minimum i wprowadzając zasadę podziału czynności wychowawczo-administracyjnych równomiernie pomiędzy wszystkich nauczycieli stałych i kontraktowych. W ten sposób starano się zwrócić uwagę władz oświatowych i społeczeństwa na ważną rolę wychowawcy i krzywdę, wyrządzoną nauczycielom przez twórców wspomnianej ustawy. Jednocześnie podjęto starania, aby szkoła średnia nie utraciła charakteru instytucji wychowawczej, chociaż zdawano sobie sprawę, że jednak szkoła na ogół na tym ucierpi ${ }^{66}$.

W następnych latach wciąż domagano się właściwego wynagradzania pracy wychowawczej, gdyż wyczerpuje ona siły i zabiera wiele czasu nie tylko w czasie nauki w szkole, ale też po jej zakończeniu. Spodziewano się, że władze szkolne wydadzą wkrótce zarządzenie, normujące wysokość wynagrodzenia za pracę wychowawcą, zakreśloną W regulaminie. ${ }^{67}$ Niestety, dopiero jedenaście lat później, w 1938 r. ówczesny Minister WRiOP W. Świętosławski złożył na posiedzeniu Rady Ministrów wniosek o przyznanie nauczycielom szkół państwowych dodatku służbowego za pełnienie czynności wychowawczych. Dodatek ten ustalono w wysokości 10 zł. Była to kwota symboliczna, nie stanowiąca wystarczającej zapłaty za pracę wymagającą całkowitego oddania się uczniom. Sądzono, że przyznanie tego dodatku stanowi zapowiedź poprawy bytu nauczycieli. Postulowano: trzeba stworzyć dla nauczyciela-wychowawcy takie warunki materialne, aby mógt poświęcić się swej pracy bez troski o jutro dla siebie i swojej rodzi$n y^{68}$.

Z. Degen-Slósarska podkreśłała, że praca wychowawcza, jeśli jest spełniana rzetelnie, zajmuje tygodniowo nawet 6-7 godzin - jeśli w szkole jest samorząd i inne organizacje młodzieżowe, to cotygodniowe posiedzenia samorządu zajmują 1 godzinę, spotkania $\mathrm{z}$ rodzicami również 1 godzinę tygodniowo - aby lepiej poznać środowisko rodzinne, okienka na zastępstwa 2-3 godziny, dobrowolna praca w jednej organizacji i dyżury pozalekcyjne - kościół, zabawy, koncerty, kino, przedstawienia uczniowskie - minimum 2 godziny tygodniowo. Przed wejściem w życie ustawy sanacyjnej na czynności wychowawcze odpłatne przewidywano 2 do 4 godziny lekcyjne tygodniowo. Z. Degen-Slósarska wyraziła więc zdziwienie, że zamiast zwiększenia wynagrodzenie za te tak pochłania-

\footnotetext{
${ }^{65}$ Nasze postulaty, „Przegląd Pedagogiczny” 1926, nr 8, s. 217.

66 W sprawie wychowawstwa, s. 677.

${ }^{67}$ R. Mańkowski, Regulamin, s. 801.

68 Wynagrodzenie za wychowawstwo, s. 303.
} 
jące dobrego wychowawcę czynności, nauczycielstwo zostało $w$ nieszczęsnej ustawie sanacyjnej zupetnie pozbawione tych skromnych wynagrodzeń za prace wychowawcze, oraz zwiększono im liczbe godzin etatu do norm, nigdzie w Europie niepraktykowanych ${ }^{69}$. W tym widziała przyczynę braku tak potrzebnego wychowawcom zapału do pracy, jej zdaniem z tego powodu nie wszyscy zrozumieli, jak ważnym wydarzeniem stało się opracowanie i wydanie Regulaminu pracy wychowawczej w szkołach średnich. Przekonywała, że aby nauczycielstwo mogło z entuzjazmem oddać się szczytnym obowiazkom pracy wychowawców w myśl wymagań, zakreślonych przez Regulamin pracy wychowawczej, trzeba jak najprędzej wydobyć nauczycieli szkół państwowych z biedy materialnej, ze stanu nieustannej troki o byt wtasny i rodzin, zatruwajacych tak potrzebna każdemu nauczycielowi-wychowawcy pogodę i radość ducha ${ }^{70}$.

\section{Uregulowania prawne pracy wychowawczej w szkołach średnich}

W sierpniu 1927 r. Ministerstwo WRiOP opracowało i wydało „Regulamin pracy wychowawczej w szkołach średnich"71. W tym samym czasie pojawiły się jeszcze dwa okólniki Ministerstwa, dotyczące wpływu wychowawczego nauczycieli na młodzież szkolną $^{72}$ oraz poziomu naukowego szkół średnich ogólnokształcących ${ }^{73}$. Wszystkie te dokumenty, jak pisał profesor J. Szczepański, dają razem wzięte, jasny, wyraźny i całkowity obraz wychowawstwa szkolnego, a tym samym sprawę tę reguluja raz na zawsze i ujednostajniaja na catym terenie Rzeczypospolitej ${ }^{74}$. Na regulamin pracy wychowawczej nauczyciele czekali już od dawna. W okólniku w sprawie regulaminu znalazł się następujący zapis: Głównym zadaniem szkoły jest wychowanie młodego pokolenia na zdrowych fizycznie i moralnie oraz uspołecznionych, państwowo-twórczych obywateli ${ }^{75}$. Szkoły mają do tego 3 środki: nauczyciela (jego indywidualność i działalność), rzetelną pracę ucznia oraz ,specjalne zabiegi, dokonywane poza godzinami lekcyjnymi na terenie szkolnym w różnych dziedzinach wychowawczych"76. Praca wychowawcza obejmuje: 1) opiekę nad poszczególnymi klasami, którą pełnią tzw. opiekunowie klasowi, 2) kierowanie pewnymi określonymi dziedzinami pracy wychowawczej - jest to zadanie wychowawców specjalnych oraz 3) szereg czynności wychowawczych, które wynikają z doraź-

\footnotetext{
${ }^{69}$ Z. Degen-Slósarska, O pracy wychowawczej w szkole, „Przegląd Pedagogiczny” 1928, nr 7, s. 150.

70 Ibidem.

${ }^{71}$ Okólnik Min. WRiOP w sprawie regulaminu pracy wychowawczej w szkołach średnich (Dz. Urz. Min. WRiOP 1927 r., nr 12, poz. 202).

${ }^{72}$ Okólnik Min. WRiOP w sprawie wpływu wychowawczego nauczycieli na młodzież szkolną (Dz. Urz. Min. WRiOP 1927 r., nr 12, poz. 203).

${ }^{73}$ Okólnik Min. WRiOP w sprawie poziomu naukowego szkół średnich ogólnokształcących (Dz. Urz. Min. WRiOP 1927 r., nr 12, poz. 201).

${ }^{74}$ J. Szczepański, Wychowawstwo w naszych szkołach średnich, „Przegląd Pedagogiczny” 1928, nr 4, s. 77.

75 Okólnik Min. WRiOP w sprawie regulaminu pracy wychowawczej..., poz. 202.

${ }^{76}$ Ibidem.
} 
nej sytuacji i potrzeb szkoły. Najważniejsza rola wychowawcza przypada opiekunom klas - regulamin powierza im cały szereg czynności, majacych na celu jak najdokładniejsze poznanie psychiki oraz warunków życia wszystkich uczniów danej klasy. W szczególności opiekun klasowy jest obowiązany wtajemniczyć się w bieg życia szkolnego młodzie$\dot{z} y$ danej klasy, poznać, jakie sa jej potrzeby i niedomagania pod względem naukowym $i$ wychowawczym ${ }^{77}$. Opiekun klasowy powinien: a) poznać warunki pracy i potrzeby swych wychowanków na terenie szkoły, b) poznać warunki ich życia poza szkoła, c) czuwać nad ich życiem i praca w szkole i porozumiewać się z gronem nauczycielskim w sprawach wychowawczych i dydaktycznych, d) opiekować się z ramienia szkoły życiem swych uczniów $w$ zakresie wychowawczym i materialnym poza szkoła i organizować $w$ miare potrzeby i możliwości koniecznej w tym zakresie pomocy, e) opiekować się utrzymaniem czystości i estetyki izby klasowej oraz w miare potrzeby estetyka wygladu samych uczniów. Krótko mówią, obowiąziem opiekuna klasowego jest uczniom swoim całkowicie się poświęcić, myśleć o nich w szkole i zajmować się ich życiem pozaszkolnym ${ }^{78}$. Regulamin był więc w zasadzie zbieżny z zapisami „Instrukcji, dotyczącej działalności wychowawczej nauczycieli w szkołach średnich ogólnokształcących”, której projekt opracowano jeszcze w 1920 r. ${ }^{79}$ W okólniku z 1927 r. pojawiła się natomiast nowa kategoria wychowawców - tzw. wychowawcy specjalni, powołani do opieki nad harcerstwem, kółkami sportowymi, samokształceniowymi, samorządem itd. Powołano tę instytucję, ponieważ niektóre prace wychowawcze nie moga być rozproszkowane przez oddzialywanie na poszczególne klasy, lecz wymagaja jednolitego kierunku $w$ organizowaniu pracy młodzieży na terenie catej szkoty ${ }^{80}$. Ponadto uznano, że kierowanie tą pracą wymaga specjalnego talentu, a często również wiedzy, którą rzadko posiadają wszyscy opiekunowie klas w danej szkole ${ }^{81}$. Zdaniem J. Szczepańskiego praca wychowawców specjalnych jest miła i wdzięczna. Łatwiej też ją wykonywać, niż pracę opiekuna klasowego. Rada Pedagogiczna powinna jednak dobrze się zastanowić, ile kółek i jakie mogą istnieć w szkole. Należy utworzyć tylko kółka najważniejsze, w największym stopniu kształcące młodzież, odpowiadające warunkom i potrzebom szkoły, i niezbyt liczne. Kółka te pełnią też rolę profilaktyczną - chronią młodzież przed niebezpieczeństwami życia pozaszkolnego. Udział w zajęciach pozalekcyjnych $w$ połaczeniu z korzyściami, które daje sama nauka, moga bez watpienia uczynić z wychowanka szkoły jednostke zdrowa fizycznie i moralnie oraz uzdolniona do życia społecznego $i$ obywatelskiego ${ }^{82}$. Jeżeli jednak młodzież będzie miała zbyt dużo zajęć pozaszkolnych, zaniedba obowiązki szkolne. A przecież nie praca w kótkach szkolnych tworzy podstawę wychowania, ale obowiązkowa praca szkolnatrzeba pamiętać, że nie wyrośnie przecież na dzielnego obywatela uczeń, który nie wytepi w sobie wrodzonego lenistwa i nie nauczyć się pracować przez sumienne spetnianie obo-

\footnotetext{
77 R. Mańkowski, Regulamin, s. 800.

78 J. Szczepański, Wychowawstwo, s. 80.

79 K. Kulwieć, H. Lipski, Projekt instrukcji, s. 74.

${ }^{80}$ R. Mańkowski, Regulamin, s. 801.

81 Ibidem.

82 J. Szczepański, Wychowawstwo, s. 79.
} 
wiązków szkolnych, choćby byt dobrym członkiem muzyki szkolnej, oddawat się gorliwie ćwiczeniom gimnastycznym i sportowi, a nawet prezentowat się należycie w hufcu szkol$n y m^{83}$. Do kółek radzono więc przyjmować tylko tych uczniów, którzy wywiązują się z obowiązków szkolnych ${ }^{84}$. Nieco inny punkt widzenia przedstawiła Z. Degen-Slósarska. Przypomniała, że specjalne dziedziny pracy wychowawczej - praca w bibliotekach, organizacjach szkolnych - istniały również w przeszłości, w szkołach byłego zaboru rosyjskiego. Po odzyskaniu niepodległości w szkołach wprowadzono samorządy szkolne, koła naukowe, sportowe, hufce harcerskie i przysposobienia wojskowego, koła Czerwonego Krzyża, czytelnie, biblioteki uczniowskie. Autorka wyraziła więc ubolewanie, że „Regulamin" krępuje dyrekcje szkół koniecznością uzyskania zgody Kuratorium na liczbę i charakter organizacji młodzieżowych. Jej zdaniem wystarczyłby zakaz organizowania niedozwolonych organizacji o charakterze międzyszkolnym lub politycznym. Jej zdaniem w regulaminie powinny znaleźć się zapisy (które były w jego projekcie) dotyczące obowiązku wychowawcy w zakresie budzenia, podtrzymywania i rozwijania uczuć narodowych, patriotycznych i rozwijania zmysłu państwowego, podnoszenia poziomu kultury obyczajowo-towarzyskiej i oddziaływania na dom rodzicielski poprzez utrzymywanie z nim stałego kontaktu ${ }^{85}$.

Praca wychowawców specjalnych stanowiła bardzo ważna dziedziną działalności szkoły, dlatego też osoby na te stanowiska wybierał dyrektor zakładu, po uprzednim wysłuchaniu opinii Rady Pedagogicznej. Dzięki temu wzrosła również rola dyrektora, który poza kontrola i ogólnym kierownictwem praca wychowawcza powinien czuwać, by zakresy prac poszczególnych wychowawców nie kolidowaty ze soba, lecz stanowity jeden zwarty system oddziaływania na młodzież $w$ kierunku, pożądanym dla narodu i Pań$s t w a^{86}$. Zadaniem dyrektora było również opracowanie szczegółowych przepisów $z$ zakresu czynności wychowawczych zarówno opiekunów klasowych, jak $i$ wychowawców specjalnych $^{87}$. R. Mańkowski był przekonany, że regulamin wywrze znaczny wplyw na podniesienie poziomu młodzieży szkolnej, chociaż jednocześnie nakłada on na nauczycielstwo poza bezpośrednimi jego obowiazkami nauczania ogrom nowej pracy i odpowiedzialności ${ }^{88}$.

Również w ustawie o ustroju szkolnictwa z 11 marca 1932 r. podkreślono rolę wychowawczą szkoły średniej ogólnokształcącej. Zgodnie z zapisem Art. 19 ustawy Szkoła średnia ogólnokształcąca ma za zadanie dać młodzieży podstawy petnego rozwoju kulturalnego, przygotować ją do czynnego udziału $w$ życiu zorganizowanego $w$ ramach państwowych społeczeństwa oraz przygotować ja do studiów w szkołach wyższych ${ }^{89}$. Natomiast w Ustawie o prywatnych szkołach i zakładach naukowych i wychowawczych

\footnotetext{
83 Ibidem, s. 80.

${ }^{84}$ Ibidem.

85 Z. Degen-Slósarska, O pracy wychowawczej, s. 149.

${ }^{86}$ Okólnik Min. WRiOP w sprawie regulaminu, poz. 202.

${ }^{87}$ Ibidem.

88 R. Mańkowski, Regulamin, s. 801.

${ }^{89}$ Ustawa z n. 11 marca 1932 r. o ustroju szkolnictwa, Dz.U. 1932, nr 38, poz. 389)
} 
z 11 marca 1932 r. napisano, że szkoła prywatna może zostać zamknięta przez władze szkolne, jeżeli jej poziom naukowy lub wychowawczy w ostatnich trzech latach był niewystarczający $^{90}$. W 1934 r. Ministerstwo WRiOP głosiło tymczasowy program nauczania, w którym określiło podstawy ideowe szkoły. We wstępie władze szkolne zapisały: Celem szkoły jest wychowanie i kształcenie młodzieży na świadomych swych obowiąków i twórczych obywateli Rzeczypospolitej. Zmierzajac do osiagnnięcia tego celu naczelnego, społeczno-obywatelskiego przygotowania swych wychowanków, szkoła musi wszechstronnie rozwijać ich osobowość przez urabianie $w$ dziedzinie religijnej, moralnej, umysłowej $i$ społecznej ${ }^{91}$. Jednak program wychowawczy szkoły powinien być dostosowany do konkretnej sytuacji $i$ do realnych możliwości, nie zaś przeładowany nadmiarem postulatów i zamierzeń, gdyż wówczas będzie jedynie piękna fikcją .

\section{Zakończenie}

Regulamin pracy wychowawczej w szkołach średnich, wydany w 1927 r., stał się podstawą do wprowadzania zapisów dotyczących czynności wychowawczych w regulaminach poszczególnych szkół średnich oraz instrukcjach i zarządzeniach dyrekcji szkół, kierowanych do wychowawców i nauczycieli. Do niego niejednokrotnie w następnych latach odwoływali się pracownicy szkoły i publicyści czasopism pedagogicznych, chociaż przeprowadzono reformę ustroju szkolnictwa, zmieniały się również warunki życia młodego pokolenia. Ten właśnie dokument można więc uznać za szczególnie dla ukształtowania się współczesnego modelu nauczyciela-wychowawcy. Natomiast treść artykułów, zamieszczonych na łamach „Przeglądu Pedagogicznego” i „Spraw Towarzystwa” skłania do refleksji nad współczesnymi zadaniami nauczyciela-wychowawcy w szkole i koniecznością przygotowania właściwych ludzi na właściwe stanowiska. Wiele postulatów, dotyczących zarówno obowiązków nauczycieli-wychowawców, jak i stawianych im wymagań, również dzisiaj nie straciło aktualności. Każdy nauczyciel powinien być wychowawcą, ale rola opiekunów klas jest szczególnie trudna do przecenienia. Należy więc zadbać o to, aby godziny wychowawcze w szkole były wykorzystywane zgodnie $\mathrm{z}$ ich przeznaczeniem, a nie traktowane jako dodatkowe lekcje z przedmiotu, którego naucza wychowawca klasy. Tylko wtedy, gdy wszyscy nauczyciele-wychowawcy zrozumieją, jak ważne są ich zadania w szkole, można będzie powiedzieć, że głównym zadaniem szkoły jest realizacja funkcji dydaktyczno-wychowawczej oraz że nauczyciele i wychowawcy klas rzeczywiście wywiązują się ze swoich obowiązków.

\footnotetext{
90 Ustawa z dnia 11 marca 1932 r. o prywatnych szkołach i zakładach naukowych i wychowawczych, Dz.U. 1932, nr 3, poz. 343)

91 M. Piątkiewicz, Podstawy ideowe naszej szkoły, „Przegląd Pedagogiczny” 1939, nr 11, s. 176.

92 Z. Kaczmarek, O poziom wychowawczy szkoły. Przyczyny paraliżujące prace nauczyciela, „Przegląd Pedagogiczny" 1938, nr 21, s. 306.
} 


\section{Bibliografia}

Araszkiewicz F.W., Ideały wychowawcze Drugiej Rzeczypospolitej, PWN, Warszawa 1978.

Araszkiewicz F.W., Szkoła średnia ogólnoksztatcaca w Polsce w latach 1918-1932, Wrocław 1972.

Araszkiewicz F.W., Tadeusza Jana Łopuszańskiego koncepcja szkoły średniej ogólnoksztatcacej, Wyd. Tow. Miłośników Rydzyny, Rydzyna 1987.

Balicki J., Wychowanie państwowe w dzisiejszej szkole średniej. Konferencja dyrektorów szkót średnich ogólnokształcacych okręgu szkolnego lwowskiego $i$ warszawskiego $w$ dniach od 10 do 15 marca 1930 r., „Przegląd Pedagogiczny” 1930, nr 13, s. 318-319.

Chirowski R., Trochę prawdy o wspótpracy domu ze szkoła, „Przegląd Pedagogiczny” 1938, nr 17-18, s. 239-243.

Degen-Slósarska Z., O pracy wychowawczej w szkole, „Przegląd Pedagogiczny” 1928, nr 7, s. $148-150$.

Fuchs F., Szkoła ogólnokształcaca jako zakład wychowawczy, „Przegląd Pedagogiczny” 1920, nr 4, s. $141-155$.

ht., Kursy dla wychowawców zorganizowane przez Koło Warszawskie TNSW, Przegląd Pedagogiczny" 1930, nr 8, s. 185-187.

J.W., Dola dyrektorów, „Przegląd Pedagogiczny” 1936, nr 5, s. 61-63.

Jakubiak K., Wychowanie państwowe jako ideologia wychowawcza sanacji, Wyd. WSP, Bydgoszcz 1994.

Jasiński W., Na przełomie myśli wychowawczej, Poznań 1936.

Jasnota-Bzowski J., Zagadnienie wspótpracy domu ze szkotą. Scylla i Charybada, „Przegląd Pedagogiczny" 1938, nr 22, s. 324-326.

Kaczmarek Z., O poziom wychowawczy szkoly. Przyczyny paraliżujace prace nauczyciela, „Przegląd Pedagogiczny" 1938, nr 21, s. 305-306.

Kiersnowski K., Zagadnienie wspótpracy domu ze szkoła. Nieporozumienie, „Przegląd Pedagogiczny" 1938, nr 21, s. 311-312.

Konferencja dyrektorów szkót średnich ogólnokształcacych okręgu szkolnego lwowskiego i warszawskiego $w$ dniach od 10 do 15 marca 1930 r., „Przegląd Pedagogiczny” 1939, nr 13, s. 318-319.

Kopia H., Ustawa o uposażeniu, „Sprawy Towarzystwa” 1923, nr 31-32, s. 485.

Kronika. Konferencje dyrektorów w sprawach wychowawczych, „Przegląd Pedagogiczny” 1929, nr 10, s. 242.

Kronika Towarzystwa. Sprawozdanie z I Zjazdu Dyrektorów Gimnazjów Państwowych w dn. 3 i 4 lutego 1922 rw Warszawie, „Sprawy Towarzystwa” 1922, nr 9, s. 6-12.

Kulwieć K., Lipski H., Projekt instrukcji dla wychowawców klasowych, „Przegląd Pedagogiczny” 1920, nr 2, s. 73-85.

Łempicki S., Polski ideał wychowawczy, Lwów 1938.

Łempicki S., Polskie tradycje wychowawcze, Warszawa 1936.

Mańkowski R., Regulamin pracy wychowawczej w szkołach średnich, „Przegląd Pedagogiczny” 1927, nr 34, s. 799-801.

Memoriat lwowskiego Zarządu Okręgowego TNSW w sprawie okólnika Kuratorium z dn. 2 grudnia 1921 r., „Sprawy Towarzystwa” 1922, nr 14, s. 20-21.

Michalski S., Działalność pedagogiczna Anieli Szycówny, Warszawa 1968.

Michalski S., Społeczna i pedagogiczna działalność Stefanii Sempołowskiej na tle epoki, Warszawa 1973.

Nasze postulaty, „Przegląd Pedagogiczny” 1926, nr 8, s. 217-218.

Nawroczyński B., Polska myśl pedagogiczna, Lwów 1933. 
Nawroczyński B., Zagadnienie wychowania narodowego, „Przegląd Pedagogiczny” 1929, nr 1, s. $6-8$.

O wychowawstwo, „Sprawy Towarzystwa” 1924, nr 22, s. 359-360.

Obowiąki opiekuna klasowego, „Sprawy Towarzystwa” 1922, nr 7, s. 3-6.

Odpowiedź Ministra Wyznań Religijnych i Oświecenia Publicznego w sprawie obowiązków wychowawcy klasy, „Sprawy Towarzystwa” 1925, nr 5-7, s. 81.

Okólnik Min. WRiOP w sprawie wpływu wychowawczego nauczycieli na młodzież szkolną (Dz. Urz. Min. WRiOP 1927 r., nr 12, poz. 203).

Okólnik Min. WRiOP w sprawie poziomu naukowego szkół średnich ogólnokształcących (Dz. Urz. Min. WRiOP 1927 r., nr 12, poz. 201).

Okólnik Min. WRiOP w sprawie regulaminu pracy wychowawczej w szkołach średnich (Dz. Urz. Min. WRiOP 1927 r., nr 12, poz. 202).

Piątkiewicz M., Podstawy ideowe naszej szkoty, „Przegląd Pedagogiczny” 1939, nr 11, s. 175-178.

Pohoska H., Wychowanie obywatelsko-państwowe, Warszawa 1931.

Przyjemski F., O polski system wychowawczy, Kraków 1930.

Ptaszycki J., Zagadnienie wspótpracy domu ze szkoła. O właściwe podejście szkoły do domu, „Przegląd Pedagogiczny” 1938, nr 23, s. 343-347.

Rendzerowa J., Zagadnienie wspótpracy domu ze szkoła. Rodzice i szkoła, „Przegląd Pedagogiczny" 1938, nr 20, s. 287-290.

Ryniewicz A., O powołaniu nauczyciela-wychowawcy, „Przegląd Pedagogiczny” 1930, nr 10, s. 227-230.

Smołalski A., Ideały wychowawcze w polskiej myśli pedagogicznej od XXI w. do końca II Rzeczypospolitej, Wyd. Uniwersytet Opolski, Opole 1994.

Smołalski A., Wizje nauczyciela w polskiej myśli pedagogicznej do 1939 r., Wyd. Uniwersytet Opolski, Opole 1997.

Sośnicki K., Podstawy wychowania państwowego, Lwów 1933.

Sprawa wychowawstwa i gospodarstwa klasowego na obszarze b. Galicji, „Sprawy Towarzystwa” 1924, nr 29, s. 466-467.

Suchodolski B., Powołanie wychowawcy, „Przegląd Pedagogiczny” 1935, nr 6, s. 89-91.

Szafran J., Dla dobra polskiej szkoły, Wyd. Poznańskie, Poznań 2010.

Szczepański J., O poziom naukowy $i$ wychowawczy w szkołach prywatnych, „Przegląd Pedagogiczny" 1929 , nr 6, s. 137-138.

Szczepański J., Wychowawstwo w naszych szkołach średnich, „Przegląd Pedagogiczny” 1928, nr 4, s. $77-81$.

Szteinbokówna E., Z aktualnych zagadnień wychowawczych, „Przegląd Pedagogiczny” 1929, nr 20, s. $478-480$.

T.B., Na tematy wychowawcze, „Przegląd Pedagogiczny” 1930, nr 24, s. 539-541.

Ustawa o uposażeniu pracowników państwowych i wojska z dn. 9 października 1923 r. (Dz. Urz. Min. WRiOP nr 20 (121) z 1 grudnia 1923 r.)

Ustawa o zapewnieniu równowagi budżetowej (Dz. U. R.P. z 1925 r., Nr 129, poz. 918).

Ustawa z dn. 11 marca 1932 r. o ustroju szkolnictwa, Dz.U. 1932, nr 38, poz. 389).

Ustawa z dnia 11 marca 1932 r. o prywatnych szkołach i zakładach naukowych i wychowawczych, Dz.U. 1932, nr 3, poz. 343).

W sprawie wychowawstwa, „Przegląd Pedagogiczny” 1926, nr 25, s. 676-678.

Wynagrodzenie za wychowawstwo, „Przegląd Pedagogiczny” 1938, nr 21, s. 302.

Z teki wychowawcy, „Sprawy Towarzystwa” 1925, nr 5-7, s. 70-73.

Ziemnowicz M., Problemy wychowania współczesnego, Warszawa 1927. 